\title{
Sparkol Videoscribe: Development of Accounting Learning Media (Case Studies in Indonesia)
}

\author{
Suranto*, Noviantin Rahayu, Lia Setyawati, Dhany Efita Sari \\ Faculty of Teacher Training and Education, Universitas Muhammadiyah Surakarta, Indonesia
}

Received June 12, 2020; Revised August 29, 2020; Accepted October 19, 2020

\section{Cite This Paper in the following Citation Styles}

(a): [1] Suranto, Noviantin Rahayu, Lia Setyawati, Dhany Efita Sari, "Sparkol Videoscribe: Development of Accounting Learning Media (Case studies in Indonesia)," Universal Journal of Educational Research, Vol. 8, No. 11B, pp. 5722-5728, 2020. DOI: 10.13189/ujer.2020.082206.

(b): Suranto, Noviantin Rahayu, Lia Setyawati, Dhany Efita Sari (2020). Sparkol Videoscribe: Development of Accounting Learning Media (Case studies in Indonesia). Universal Journal of Educational Research, 8(11B), 5722-5728. DOI: 10.13189/ujer.2020.082206.

Copyright $\odot 2020$ by authors, all rights reserved. Authors agree that this article remains permanently open access under the terms of the Creative Commons Attribution License 4.0 International License

\begin{abstract}
The purpose of this study is to produce sparkol videoscribe-based learning video products that are suitable to be used in journalizing trade accounting journals with a spreadsheet program. The type of research used was research and development. The development procedure in this study was the ADDIE model, which consisted of analysis, design, development, implementation, and evaluation. This research was conducted in two stages, namely a limited trial phase and an experimental stage to a larger class. This sparkol videoscribe learning video contained tutorial material for journalizing trade accounting with a spreadsheet program. Before conducting trials and experiments with students, this learning video has been assessed for eligibility by material experts and media experts. The results of the material experts obtained a final score of 3.47 (very feasible), while the media experts obtained a score of 3.2 , which means feasible. The results of the researchers tested the feasibility of learning media obtained from the distribution of questionnaires to students that at the trial stage, the average questionnaire score was 3.05 (feasible). In addition, at the experimental stage, the results obtained an average questionnaire score of 3.07 (feasible). The results of the research development process have proven that sparkol videoscribe is feasible to be used in learning spreadsheets for accounting.
\end{abstract}

Keywords Learning Media, Sparkol Videoscribe, Spreadsheet Accounting

\section{Introduction}

The effects of globalization have led to the development of science and technology. There is a cohesiveness and integrity of the world that requires in-depth study, allocation of resources, and facilities to encourage innovation, creativity, and high social mobility in improving the global education system (Assare, Mohammadi, Foroufan, \& Salehizadeh, 2016). Various countries compete with each other to improve the quality of their education system. It is evidenced by the research of the education system in several countries, such as Russia, Finland, Britain, Lithuania, etc. (Assare et al., 2016; Zygaitiene \& Buivydaite, 2017). Thus, other countries should adapt to the progress at the global level, especially in the fields of education, science, and technology.

One of the breakthroughs in the development of science and technology today is the renewal of the use of technology in the learning process in elementary schools, secondary schools, and tertiary institutions (Trepule, Tereseviciene, \& Rutkiene, 2015; Goldie, 2016). The renewal is to improve the quality of global education. Thus, educators are required to have digital skills associated with the learning process. According to (Youssef, Dahmani, \& Omrani, 2013), the involvement of students in the use and utilization of technology in the learning process can improve their electronic skills. Teachers as the educators who have full responsibility must have digital skills, which in turn create appropriate learning strategies in digital-based learning processes so that they can achieve 
learning goals. Digital also falls into the six basic literacies that must be applied in the education unit (World Economy Forum, 2015). Therefore, the state is also responsible for implementing literacy and putting it into the category of professional educators, educators who have a good level of digital literacy. Britain, Europe, and other parts of the world often use the terms "technology can enhance learning" and "technology-enhanced learning", or often referred to as e-learning (Kirkwood \& Price, 2014).

One way to design learning strategies that can attract students' interest is to use interesting learning media. According to Mateer (2011), the effective use of media engages students' interests, improves the depth and retention of knowledge, motivates interest in learning, and can be used to illustrate the relevance of concepts. The existing education model emphasizes the use of appropriate teaching and learning strategies to achieve learning outcomes. At present, it is inevitable that higher education also follows the trend to change education by integrating it through technology (Yang \& Lau, 2017). Technological developments and increased accessibility to the internet and mobile media devices, coupled with the increased use of software and institutional support, have led to the acceleration of the development of computer-aided instructions in tertiary institutions (Campbell, 2005). Academic institutions are increasingly integrating new Information and Communication Technology (ICT) into their education systems such as e-learning platforms, tablet PCs, instant messaging software, videogames, and virtual reality (Blasco-Arcas, Buil, Hernández-Ortega, \& Sese, 2013; Dündar \& Akçayir, 2014).

According to Bingimlas (2009), the use of ICT in the classroom is essential to provide opportunities for students to learn to operate in the information age. Technology shows many new characteristics that can be applied to make instruction more attractive to students (Keller \& Suzuki, 2004). ICT is a fundamental tool to support learning activities (Huffman \& Huffman, 2012; Torres-Ramírez, García-Domingo, Aguilera, \& De La Casa, 2014). As stated by Mishra \& Koehler (2006), technology plays a decisive role in developing good teaching. By combining content, pedagogy, and technology, the use of ICT encourages students' motivation and improves their learning outcomes compared to more traditional educational facilities in the classroom. Technological advances in recent years have made computers vital in education by offering new learning media, content, and strategies that are served through computers. Therefore, computer-based technology is gaining high attention in higher education (Tlili, Essalmi, Jemni, Kinshuk, \& Chen, 2016). Magen-Nagar \& Peled (2013) state that computerized learning tools can make many changes in teaching and learning and thinking.

One of the IT-based learning media that can be used by educators is Sparkol Videoscribe, a software used to create animated videos. The unique characteristic of sparkol videoscribe is that it can present learning content by combining images, sound, and design. The features provided by this application are very diverse so that they become learning media that can be adapted to the various subject matter (Pamungkas, Ihsanudin, Novaliyosi, \& Yandari, 2018). Therefore, by using sparkol videoscribe based learning videos, it is expected to make learning more engaging, easy to carry anywhere to learn, and more environmentally friendly because it is paperless.

The learning video developed in this study is a video tutorial of journalizing trade accounting which can be used in universities in Indonesia. When using videos to provide tutorials, videos generally must achieve two objectives. First, the goal is to support the performance of the task, meaning the video must be able to guide the completion of the task for the user. Second, the aim is to support learning, and the video must instruct users to perform various tasks independently (Grabler, Agrawala, Li, Dontcheva, \& Igarashi, 2009; Meij, Karreman, \& Steehouder, 2009).

The results of research conducted by Meij \& Meij (2014) showed that participants who worked with paper-based tutorials could complete $63 \%$ of the training assignments, while participants who had watched the videos achieved an $87 \%$ success rate. Based on this analysis, it can be concluded that participants who have received video instructions are faster in completing training assignments than those who use paper-based tutorials. Based on the existing problems, this study aims to produce a product in the form of learning videos based on sparkol videoscribe in journalizing trade accounting that is feasible to use, and to improve the quality of learning and learning outcomes of studying Accounting in Indonesia.

\section{Research Methods}

\subsection{Types of Research}

This research belongs to the type of research and development ( $R \& D)$. The development procedure used the ADDIE model that refers to Aldoobie (2015), with five instructional design processes, namely Analysis, Design, Development, Implementation, and Evaluation. 1) Analysis: analyzing the needs of learning media journalizing trade accounting using a questionnaire. 2) Design. In this stage, the researcher developed sparkol videoscribe software as a learning medium. 3) The development of the sparkol results that had been made was then assessed for their suitability by material experts and media experts. 4) Implementation. Sparkol which was feasible would be tested on all respondents. 5) Evaluation: evaluating the feasibility of sparkol based on the assessment of respondents.

\subsection{Research Subject}

The study was conducted on students who were taking 
spreadsheets for accounting courses in the Accounting Education Study Program at the Universitas Muhammadiyah Surakarta (UMS), Indonesia. Students in the spreadsheet for accounting subject class are used as subjects of product development trials. The results of the development trial analysis are used to evaluate and improve the development of this sparkol video scribe product.

\subsection{Data Collection and Analysis Techniques}

Data collection techniques in this study used a questionnaire containing questions about the feasibility of the media that was tested on students. Indicators of eligibility questionnaires consisted of conformity with teaching objectives, material taught, supporting facilities, environmental conditions, and time, characteristics and learning styles of students. The data would be strengthened by comments and suggestions from expert assessments and the results of interviews with several students after using sparkol videoscribe as a learning medium in the spreadsheet for accounting courses. Meanwhile, the analysis technique employed was a quantitative analysis technique. Quantitative analysis was obtained from a questionnaire containing questions about the feasibility of sparkol that has been tested on students, then the percentages were analyzed descriptively and percentage descriptive analysis criteria referred to Riduan (2004: 71-95).

\section{Results and Discussion}

The results of research and development of sparkol videoscribe-based learning media contained tutorials on journalizing trade accounting through spreadsheet courses. This research had two stages of implementation, namely: 1) The product trial phase carried out in a limited scale field trial to three students. 2) The stage of experiments conducted on two different classes of students who were taking a spreadsheet for accounting courses. The ADDIE development model used in the study had five design processes, including Analysis, Design, Development, Implementation, and Evaluation. The discussion of the ADDIE model instructional design process in this study is as follows:

\subsection{Analysis}

The analysis referred to in this study is an analysis of the needs of instructional media by students in the spreadsheet for accounting courses in the UMS Accounting Education Study Program. The analysis of learning media needs was done by analyzing the learning media needs questionnaire that had been distributed to all respondents. The learning media needs questionnaire contained ten statements with answer choices "Yes" (given a value of 1 ) and answers "No" (given a value of 0 ), then the data from each answer was summed and in percentage. From the percentage results, the number of students who needed the development of instructional media through video is presented.

The analysis results of the learning media needs are presented in table 1. From the results, it can be concluded that, of the total number of respondents, 30 students $(100 \%)$ stated that so far, the lecturer has never used other learning media besides the handbook currently used. Besides, 30 students $(100 \%)$ wanted variations in other learning media besides books. Twenty-six students (87\%) thought that the use of learning videos is more interesting than the use of textbooks. As many as 25 students (83\%) wanted the learning media in the form of learning videos. Besides, the same percentage also showed that as many as $83 \%$ of students wanted a learning media with full-color display and equipped with animation. As many as 24 students $(80 \%)$ wanted a learning media accompanied by sound and music. Moreover, the same percentage also showed that as many as $80 \%$ of students wanted learning media that could be used independently. As many as 27 students (90\%) wanted a learning media that displayed not too long texts. As many as 28 students (93\%) wanted the learning media displayed on one computer screen with the work being done.

Table 1. Results of Questionnaire Analysis of Learning Media Needs

\begin{tabular}{|c|c|c|c|c|c|}
\hline \multirow{2}{*}{ No } & \multirow{2}{*}{ Questions } & \multicolumn{2}{|c|}{ Answer } & \multicolumn{2}{|c|}{ Percentage } \\
\hline & & Yes & No & Yes & No \\
\hline 1. & Have used other learning media besides books & 0 & 30 & $0 \%$ & $100 \%$ \\
\hline 2. & Students want other learning media. & 30 & 0 & $100 \%$ & $0 \%$ \\
\hline 3. & $\begin{array}{l}\text { More interesting learning media: If it is a learning video, select "Yes" If it is a book, then } \\
\text { select the answer "No". }\end{array}$ & 26 & 4 & $87 \%$ & $13 \%$ \\
\hline 4. & Students want media in the form of learning videos. & 25 & 5 & $83 \%$ & $17 \%$ \\
\hline 5. & Want learning media looks full color & 25 & 5 & $83 \%$ & $17 \%$ \\
\hline 6. & Want learning media accompanied by sound and music & 24 & 6 & $80 \%$ & $20 \%$ \\
\hline 7. & Want media that displays text not too long & 27 & 3 & $90 \%$ & $10 \%$ \\
\hline 8. & Want learning media equipped with animation & 25 & 5 & $83 \%$ & $17 \%$ \\
\hline $\begin{array}{c}9 . \\
10 .\end{array}$ & $\begin{array}{l}\text { Want learning media that can be studied independently } \\
\text { Learning media can be displayed on one computer layer with what is being done. }\end{array}$ & $\begin{array}{l}24 \\
28\end{array}$ & $\begin{array}{l}6 \\
2\end{array}$ & $\begin{array}{l}80 \% \\
93 \%\end{array}$ & $\begin{array}{c}20 \% \\
7 \%\end{array}$ \\
\hline
\end{tabular}


Findings from the results of a questionnaire analysis of learning media needs showed that digital media was very much needed in learning activities. Real conditions at this time, there must be a clear follow-up between the development of digital media and learning in education (Herro, 2015; Firdaus, 2018). For this reason, researchers offered digital learning media in the form of learning videos developed using sparkol videoscribe. Sparkol videoscribe was selected because it can present learning content that combines images/animation, sound, music, and full-color display. Besides, it can be adjusted to the content of the subject matter, various types of music both with fast and slow rhythms; then it can also be added with sound, as well as a diverse background screen.

\subsection{Design}

Based on the questionnaire of the learning media needs that have been analyzed, it can be seen that there was a need for the development of video-based learning media. According to Ginting, Saragi, \& Lubis (2018), one of the factors that influence low learning outcomes is the lack of variety in learning media. The design in the development of video-based learning media should be made in color (full color), accompanied by music and explanatory sound (narration), the text should not be too long, accompanied by images or animations, and the video can be displayed on one computer screen with the work being done (i.e., make financial reports on Ms. Excel). Therefore, researchers developed learning media using sparkol videoscribe software because it presents various features. In addition to making learning videos, researchers also used other software, Windows Movie Maker, which was used as a tool to edit videos.

In addition to making learning videos, question sheets were also made, which contained questions about trading company financial statement cases. This case problem was used to train students in completing financial statements of trading companies through spreadsheet media in Microsoft Office Excel. The cover on this question sheet was created with the help of the Canva application, while for case questions, the financial statements were made using Microsoft Office Word. Canva is an online design program offering various editing tools for creating various graphic designs such as book covers, posters, presentations, and so on.

\subsection{Development}

The development phase is the implementation of the design that has been made. The results of the product before the feasibility assessment after the learning media has been completed, then the assessment of the feasibility of instructional media was carried out by material experts and media experts. There were two experts in the material in this study, namely lecturers who handled spreadsheets for accounting courses, while media experts were lecturers who were experts in the field of teaching materials and learning media in the Accounting Education Study Program, Universitas Muhammadiyah Surakarta.

Assessment of the feasibility of this learning media was carried out using a questionnaire containing 15 statements. The assessment in this questionnaire employed the Likert scale, which has the lowest score to the highest score (Creswell, 2014). This questionnaire had four assessment scores, consisting of answers: Disagree, got a score of 1 ; Less agree, got a score of 2; Agree, got a score of 3; and Strongly agree, got a score of 4 . Furthermore, the assessment results were calculated for the acquisition of scores and determined the eligibility criteria for learning media. The assessment results of sparkol videoscribe based learning media by material experts and media experts can be seen in table 2 and table 3 .

Table 2. Results of the Feasibility Assessment of Learning Media by Material Experts

\begin{tabular}{|c|c|c|c|c|}
\hline \multicolumn{2}{|c|}{ Number of Questions } & Total & Maximum & Criteria \\
\hline Expert Material 1 & 15 & 54 & 60 & Very feasible \\
\hline Expert Material 2 & 15 & 50 & 60 & Very feasible \\
\hline Total score & & & 104 & \\
\hline Average score $(\overline{\mathrm{X}})$ & & & 3.47 & \\
\hline Criteria & & Ver & feasible & \\
\hline
\end{tabular}

Table 3. Results of Learning Media Feasibility Assessment by Media Experts

\begin{tabular}{|c|c|c|c|c|}
\hline \multicolumn{2}{|c|}{ Number of Questions } & $\begin{array}{c}\text { Total } \\
\text { Score }\end{array}$ & $\begin{array}{c}\text { Maximum } \\
\text { Score }\end{array}$ & Criteria \\
\hline Media Expert & 15 & 48 & 60 & Very feasible \\
\hline Total score & & & 48 & \\
\hline Average score $(\overline{\mathrm{X}})$ & & & 3.2 & \\
\hline Criteria & & & Feasible & \\
\hline
\end{tabular}

Based on the feasibility test table of the learning video by the two material experts, the results of the assessment of Expert Material 1 obtained a result of 3.6 or got the criteria of "Very Feasible". Meanwhile, the results of the assessment of Expert Material 2 obtained a result of 3.33 or got the criteria of "Very Feasible". Besides, the feasibility of learning media based on material experts obtained the final result of 3.47 or got the criteria "Very Feasible". In addition, based on the results of the media feasibility test by media experts, the final results of the media feasibility were 3.2 or got a "Feasible" criterion. A list of learning media revisions is presented in table 4 . 
Table 4. Revision List of Sparkol Videoscribe Based Learning Media

\begin{tabular}{|c|c|c|}
\hline Expert Material 1 & Expert Material 2 & Media Expert \\
\hline $\begin{array}{c}\text { In the material of General } \\
\text { Journal workshet number } \\
\text { co-2f, the blocked account } \\
\text { code column is starting from } \\
\text { the account code table down, } \\
\text { not from the entire column. }\end{array}$ & $\begin{array}{c}\text { The } \\
\text { accompaniment } \\
\text { music is too loud, } \\
\text { so it interferes with } \\
\text { the audio } \\
\text { instructions. }\end{array}$ & $\begin{array}{c}\text { The screen } \\
\text { background is only } \\
\text { white, needs color } \\
\text { consideration. }\end{array}$ \\
$\begin{array}{c}\text { Each stage of formula writing } \\
\text { is better accompanied by a } \\
\text { display picture of the writing } \\
\text { steps. }\end{array}$ & $\begin{array}{c}\text { In displaying the } \\
\text { teps of writing the } \\
\text { formula, the } \\
\text { duration needs to be } \\
\text { added. }\end{array}$ & $\begin{array}{c}\text { Lack of animation } \\
\text { (80\% of writing). }\end{array}$ \\
$\begin{array}{c}\text { In the additional tips material } \\
\text { for }\end{array}$ & $\begin{array}{c}\text { Give a description } \\
\text { on YouTube about } \\
\text { application number 5, moved } \\
\text { to the worksheet material } \\
\text { General journal } \\
\text { duration. }\end{array}$ \\
\hline & & $\begin{array}{c}\text { In the description } \\
\text { box on YouTube, } \\
\text { insert the link to } \\
\text { download the }\end{array}$ \\
\hline
\end{tabular}

\subsection{Implementation}

Implementation is a step to try out the learning media that have been made after going through the previous development stages. In accordance with its objectives, Sparkol Videoscribe-based learning media was implemented in the spreadsheet for accounting courses in the UMS Accounting Education Study Program. However, before conducting experiments in the classroom, researchers first tested the learning media to three students who were taking a spreadsheet for the accounting course. Trials on the three students were conducted at different times. When the results of trials on three students have been declared "feasible", then experiments were conducted on all students with two classes of spreadsheets for accounting courses. Experiments were performed for two consecutive days.

\subsection{Evaluation}

The last stage of this development research is evaluating the learning media that has been implemented. This evaluation phase was carried out by giving a questionnaire about the feasibility of learning media to students after trying to use instructional media in the form of sparkol videoscribe. This research instrument utilized a learning media feasibility questionnaire containing 20 statements. The assessment in this questionnaire employed the Likert scale, which consisted of four assessment scores, namely answers: Disagree, got a score of 1; Less agree, got a score of 2; Agree, got a score of 3; and Strongly agree, got a score of 4 . Besides, interviews were also conducted with several students who have tried to use learning media.

The feasibility questionnaire for instructional media based on student assessment distributed to 30 students was conducted in two stages, namely the testing phase and the experimental stage. The trial phase conducted on three students showed that the average score of the media eligibility questionnaire obtained a score of 3.05 or got the criteria "Feasible". Besides, based on the results of interviews with three respondents, it can be concluded that they were more interested in using instructional media in the form of learning videos based on sparkol videoscribe compared to books since the use of Sparkol Videoscribe-based learning videos created more fun of learning and it is easier to understand.

The experimental stage of 27 students in two classes showed that the average score for the media eligibility questionnaire was 3.07 or got the "Feasible" criteria. In addition, based on the results of interviews with the two respondents, it can be concluded that they were more interested in using instructional media in the form of video learning based on sparkol videoscribe compared to books since the use of learning videos made learning more varied and not boring because there are pictures/animations in it. Other respondents also stated that by using video, learning became more efficient, and subject matter could be learned anywhere without having to bring books.

In line with previous research by Luke \& Hogarth (2011), the result obtained that the development of a short video tutorial on the subject of accounting in postgraduate as a means of helping students develop and improve independent learning skills got positive findings in terms of teaching and learning that became more efficient and effective. Five short video tutorials (around 5-10 minutes) were introduced as an effort to shift dependency in learning from lecturer to student. Data were collected in the form of data on the use of online student video tutorials, and students commented on the questionnaire collected over three semesters from 2008 to 2009. Interviews with students were conducted at the end of 2009 to evaluate comprehensively further. The results of the media feasibility assessment at the experimental stage are presented in table 5 .

Based on the results table of the feasibility assessment of instructional media at the experimental stage, it can be concluded that the Sparkol Videoscribe-based learning media on material for journalizing trade accounting through spreadsheet program is feasible for use in learning spreadsheets for accounting in the UMS Accounting Education Study Program. It can be seen from the results of the questionnaire assessment of the feasibility of learning media by students that at the product trial stage, the results were 3.05 or got the "Feasible" criteria, and the experimental stage obtained the results at 3.07 or got the "Feasible" criteria. In addition, the feasibility questionnaire for learning media to 30 students obtained the final result of 3.06 or got the "Feasible" criteria. Besides, in an interview with five students, it can be concluded that Sparkol Videoscribe-based learning videos were more interesting than handbooks because they made learning more fun, easier to understand the material, made learning more varied and not boring, more efficient. The subject matter could be learned anywhere without having to bring books. 
Table 5. Results of Learning Media Feasibility Assessments at the Experimental Stage

\begin{tabular}{|c|c|c|c|c|c|}
\hline \multirow[b]{2}{*}{ No } & \multirow[b]{2}{*}{ Questions } & \multicolumn{4}{|c|}{ Number of students who choose answers } \\
\hline & & Disagree & Less Agree & Agree & $\begin{array}{c}\text { Strongly } \\
\text { Agree }\end{array}$ \\
\hline 1. & The material is in accordance with the learning objectives. & 3 & 2 & 16 & 6 \\
\hline 2. & Clarify and facilitate understanding & - & 2 & 18 & 7 \\
\hline 3. & Improve the ability to journalize trade accounting & - & 3 & 19 & 5 \\
\hline 4. & Images/animations can clarify the material. & 1 & 2 & 19 & 5 \\
\hline 5. & $\begin{array}{l}\text { Conformity between the material and the ability to operate a } \\
\text { spreadsheet program }\end{array}$ & 1 & 3 & 18 & 5 \\
\hline 6. & Neat and explicit material & 1 & 1 & 14 & 11 \\
\hline 7. & Complete material in accordance with the handbook & - & 2 & 16 & 9 \\
\hline 8. & Can be used whenever and wherever & - & 1 & 14 & 12 \\
\hline 9. & Media, in accordance with the conditions of the learning environment & - & 1 & 24 & 2 \\
\hline 10. & Media duration can be adjusted (fast/slow). & - & 3 & 16 & 8 \\
\hline 11. & Adequate facilities and infrastructure & 1 & 9 & 14 & 3 \\
\hline 12. & Sentences and language are easy to understand. & - & 2 & 22 & 3 \\
\hline 13. & $\begin{array}{l}\text { Accompanying music and narration make the atmosphere interesting \& } \\
\text { not boring }\end{array}$ & - & 2 & 18 & 7 \\
\hline 14. & The voice and accompaniment of music (back sound) do not interfere. & - & 6 & 15 & 6 \\
\hline 15. & Simplify spreadsheet assignments & 1 & 5 & 15 & 6 \\
\hline 16. & Media operated easily & - & 1 & 21 & 5 \\
\hline 17. & Media can be studied independently. & - & 4 & 19 & 4 \\
\hline 18. & The use of media increases interest in learning. & - & 7 & 16 & 4 \\
\hline 19. & Increase learning motivation & - & 4 & 18 & 5 \\
\hline \multirow[t]{4}{*}{20.} & $\begin{array}{c}\text { Prefer media with a complete presentation in the form of text, images, } \\
\text { sound, and music }\end{array}$ & - & 1 & 21 & 5 \\
\hline & Total score & & \multicolumn{2}{|c|}{1661} & \\
\hline & Average score $(\overline{\mathbf{X}})$ & & \multicolumn{2}{|c|}{3.07} & \\
\hline & Criteria & & \multicolumn{2}{|c|}{ Feasible } & \\
\hline
\end{tabular}

\section{Conclusions}

In the existence of integration between technology and information development with education, the researchers offer the development of instructional media in the form of sparkol videoscribe in spreadsheets for accounting courses in tertiary institutions. Based on the results of the feasibility test by material experts, the final score was 3.47 (Very Feasible), and the results of the feasibility test by media experts obtained a final score of 3.2 (Feasible), as well as, student assessment through a questionnaire obtained the final result of 3.06 (Feasible). It was concluded that Sparkol Videoscribe-based learning media was appropriate to be used as an alternative in learning spreadsheets for accounting. Accounting learning became more varied and in the learning video, some pictures/animations could help students understand the material, accompanied by narration, which could be studied independently, environmentally friendly, and efficient. Limitations in this development were found in Sparkol Videoscribe software, where the software has weaknesses, such as the difficulty in pausing the video when recording sound. Then, if the content is too much, sometimes the software stops operating for a moment. Also, when it is made into full video format, the process of waiting takes quite a long time.

\section{REFERENCES}

[1] Aldoobie, N. (2015). ADDIE Model. American International Journal of Contemporary Research, 5(6), 68-72.

[2] Assare, A. R., Mohammadi, M., Foroufan, M., \& Salehizadeh, M. (2016). The Impact of Globalization on Africa. Journal of Administrative Management, Education and Training, 12(5), 27-33. https://doi.org/10.1007/978-1-3 49-26675-3_7

[3] Bingimlas, K. A. (2009). Barriers to the Successful Integration of ICT in Teaching and Learning Environments: A Review of the Literature. Eurasia Journal of Mathematics, Science \& Technologi Educational, 5(3), 235-245. https://doi.org/10.1108/09578230310464666

[4] Blasco-Arcas, L., Buil, I., Hernández-Ortega, B., \& Sese, F. J. (2013). Using clickers in class. the role of interactivity, active collaborative learning and engagement in learning performance. Computers and Education, 62, 102-110. https://doi.org/10.1016/j.compedu.2012.10.019

[5] Campbell, G. (2005). There's Something in the Air: 
Podcasting in Education. Educause Rev

NovemberDecember, (2), 33-44. https://doi.org/http://www .cblt.soton.ac.uk/multimedia/PDFs08/Podcasting\%20in\%20 education.pdf

[6] Creswell, J. w. (2014). Research Design: Qualitative, Quantitative, and Mixed Methods Approaches.

[7] Dündar, H., \& Akçayir, M. (2014). Implementing Tablet PCs in Schools: Students' Attitudes and Opinions. Computers in

Human Behavior, 32, 40-46. https://doi.org/10.1016/j.chb.2 013.11 .020

[8] Firdaus, T. (2018). Pemanfaatan Media berbasis Teknologi dan Pembelajaran [The Use of Technology-Based Media and Learning]. Artikel: Media Pembelajaran STKIP, p. 4.

[9] Ginting, S. B., Saragi, D., \& Lubis, W. (2018). Developing Video Based Learning Media with Scientific Approach of Grade 4th Elementary School. Advances in Social Science, Education and Humanities Research, 200, 729-731. https://doi.org/10.2991/aisteel-18.2018.158

[10] Goldie, J. G. S. (2016). Connectivism: A knowledge learning theory for the digital age? Medical Teacher, 38(10), 1064-1069.

https://doi.org/10.3109/0142159X.2016.1173661

[11] Grabler, F., Agrawala, M., Li, W., Dontcheva, M., \& Igarashi, T. (2009). Generating photo manipulation tutorials by demonstration. ACM Transactions on Graphics, 28(3), 110. https://doi.org/10.1145/1531326.1531372

[12] Herro, D. (2015). Sustainable Innovations: Bringing Digital Media and Emerging Technologies to the Classroom. Theory into Practice, 54(2), 117-127.https://doi.org/10.108 $0 / 00405841.2015 .1010834$

[13] Huffman, W. H., \& Huffman, A. H. (2012). Beyond Basic Study Skills: The Use of Technology for Success in College. Computers in Human Behavior, 28(2), 583-590. https://doi.org/10.1016/j.chb.2011.11.004

[14] Keller, J., \& Suzuki, K. (2004). Learner motivation and E-learning design: A multinationally validated process. Journal

of Educational Media, 29(3), 229-239. https://doi.org/10.10 $80 / 1358165042000283084$

[15] Kirkwood, A., \& Price, L. (2014). Technology-Enhanced Learning and Teaching in Higher Education: What is "Enhanced" and How do we Know? A Critical Literature Review. Learning, Media and Technology, 39(1), 6-36. https://doi.org/10.1080/17439884.2013.770404

[16] Luke, B., \& Hogarth, K. (2011). Developing and Enhancing Independent Learning Skills Using Video Tutorials as a Means of Helping Students Help Themselves. Accounting Research Journal, 24(3), 290-310. https://doi.org/10.1108/1 0309611111187019

[17] Magan-Nagar, N., \& Peled, B. (2013). Characteristics of Israeli School Teachers in Computer-Based Learning Environments. Journal of Educators Online, 10(1), 1-34. https://doi.org/10.9743/JEO.2013.1.2

[18] Mateer, G. (2011). Using Media to Enhance Teaching and
Learning. Starting Point: Teaching and Learning Economics. http://serc.carleton.edu/econ/media/index.html

[19] Meij, H. Van Der, Karreman, J., \& Steehouder, M. (2009). Professional Practice on Printed Software. Technical Communication, 56(3), 265-292.

[20] Meij, H. Van Der, \& Meij, J. Van Der. (2014). A Comparison of Paper-Based and Video Tutorials for Software Learning. Computers and Education, 78, 150-159.https://doi.org/10.1 016/j.compedu.2014.06.003

[21] Mishra, P., \& Koehler, M. J. (2006). Technological Pedagogical Content Knowledge: A Framework for Integrating Technology in Teacher Knowledge. Teachers College Record, 108(6), 1017-1054.

[22] Pamungkas, A. S., Ihsanudin, Novaliyosi, \& Yandari, I. A. V. (2018). Video Pembelajaran Berbasis Sparkol Videoscribe: Inovasi Pada Perkuliahan Sejarah Matematika [Sparkol Videoscribe-Based Learning Videos: Innovation in the History Mathematical]. Prima: Jurnal Pendidikan Matematika, 2(2), 127-135. https://doi.org/10.31000/prima. v2i2.705

[23] Riduan. (2004). Belajar Mudah Penelitian untuk Guru-Karyawan dan Peneliti Pemula [Easy Learning Research for Teacher-Employees and Novice Researchers]. Bandung: Alfabeta.

[24] Tlili, A., Essalmi, F., Jemni, M., Kinshuk, \& Chen, N. S. (2016). Role of Personality in Computer Based Learning. Computers in Human Behavior, 64, 805-813. https://doi.org/10.1016/j.chb.2016.07.043

[25] Torres-Ramírez, M., García-Domingo, B., Aguilera, J., \& De La Casa, J. (2014). Video-Sharing Educational Tool Applied to the Teaching in Renewable Energy Subjects. Computers and Education, 73, 160-177. https://doi.org/10.1016/j.comp edu.2013.12.014

[26] Trepule, E., Tereseviciene, M., \& Rutkiene, A. (2015). Didactic Approach of Introducing Technology Enhanced Learning (TEL) Curriculum in Higher Education. Procedia Social and Behavioral Sciences, 191, 848-852. https://doi.org/10.1016/j.sbspro.2015.04.340

[27] WEF. (2015). New Vision for Education Unlocking the Potential of Technology. AIP Conference Proceedings. https://doi.org/10.1063/1.4938795

[28] Yang, I., \& Lau, B. T. (2017). Effects of Using Learners' Produced Screencast as Worked Examples in Learning. EAI Endorsed Transactions on E-Learning, 4(15), 1-11. https://doi.org/10.4108/eai.29-11-2017.153390

[29] Youssef, A. Ben, Dahmani, M., \& Omrani, N. (2013). Information Technologies, Students' e-Skills and Diversity of Learning Process. Education and Information Technologies, 20(1), 141-159. https://doi.org/10.1007/s106 39-013-9272-x

[30] Žygaitienè, B., \& Buivydaite, E. (2017). Preparation of Technology Education Teacher in Lithuania, Finland and Great Britain. Rural Environment, Education, Personality, 408-415. 